\title{
OKOS GYÁRTÁS ÉS MODERN KARBANTARTÁS A MAI MAGYAR JÁRMÜIPARBAN
}

\section{SMART MANUFACTURING AND MODERN MAINTENANCE IN TODAY'S HUNGARIAN VEHICLE INDUSTRY}

\author{
Juhász László*, Pokorádi László \\ ${ }^{1}$ Biztonságtudományi Doktori Iskola, Óbudai Egyetem, Magyarország \\ ${ }^{2}$ Mechatronikai és Jármütechnikai Intézet, Bánki Donát Gépész és Biztonságtechnikai Mérnöki Kar, Óbudai \\ Egyetem, Magyarország \\ https://doi.org/10.47833/2021.1.ENG.013
}

\section{Kulcsszavak: \\ Ipar 4.0 \\ okos gyártás \\ IoT \\ karbantartás \\ járműipar}

\section{Keywords:}

Industry 4.0

Smart manufacturing

IoT

maintenance

vehicle industry

\section{Cikktörténet:}

Beérkezett 2021. március 20.

Átdolgozva 2021. április 15.

Elfogadva 2021. április 25.

\begin{abstract}
Összefoglalás
Tanulmányunk a hazai jármüiparban végzett felmérés eredményeit mutatja be. Ennek keretében a karbantartási ágazatban lévő jelenlegi trendeket vizsgáltuk. Különösen az okos gyártás és a modern eszközök karbantartásra gyakorolt hatásaival foglalkoztunk. Az adott válaszokat elemeztük és közöttük összefüggéseket kerestünk.
\end{abstract}

\begin{abstract}
This paper presents the results of a survey conducted in the domestic automotive industry. In this context, we examined current trends in the maintenance sector. In particular, we addressed the effects of smart manufacturing and modern devices on maintenance. We analyzed the given answers and looked for correlations between them.
\end{abstract}

\section{Bevezetés}

Jelenleg az iparban forradalmi paradigmaváltás megy végbe, egyre inkább általánosan használttá válnak olyan okos, digitális megoldások, mint például a kooperatív robotok (angolul: cooperative robots - cobots) vagy az ipari 3D nyomtatás. Ezeket az Ipar 4.0 trendeket a koronavírus járvány csak tovább fokozta. Morauszki megfogalmazása szerint Ipar 4.0 a negyedik ipari forradalom, mely az információs technológia és az automatizálás összefonódását jelenti [10]. Az Ipar 4.0 adta lehetőségeket, megoldásokat már használják az járműipari vállalatok, mely egyik fő alkotó eleme az loT (Internet of Things - a dolgok internete).

Ezen alkalmazások egyik legnagyobb hasznosítási formája az ipari üzemeltetés és karbantartás. A korábbi kutatásaink során azzal foglalkoztunk, hogy ennek a digitális forradalomnak az eszközei hogyan hatnak a karbantartási folyamatokra. Ebből a szempontból megvizsgáltuk a kiterjesztett valóság (angolul: Augmented Reality - AR) [7]; és az Ipari Dolgok Internete [6] befolyásoló hatását is.

Fontos kérdés azonban, hogy ezek a trendek mennyire hatnak a hazánk ipari szereplőire,

\footnotetext{
* Kapcsolattartó szerző. Tel.: +36 207773872

E-mail cím: j.laszlo92@stud.uni-obuda.hu
} 
milyen mértékben jelentek meg az általános szakmai stratégiájukban. Tanulmányunkban arra keresünk választ, hogy a kérdéskör iránt érdeklődő magyar karbantartási szakemberek számára melyek a jelenlegi általánosabb trendek, ezekben mennyire jelennek meg az új típusú technológiák.

Magyarországon az egyik legfejlettebb iparágnak a jármüipar mondható. Hazánkban egy egész vállalatra, illetve a karbantartási folyamatokra vonatkozó innovációk sokszor itt jelennek meg. Ezért mikro-kísérletünket jármüipari szereplők körében végeztük el kérdőíves vizsgálat formájában.

A felméréssel a célunk nem csak az, hogy rávilágítsunk a hazai jármüipar aktuális állapotára, hanem az, hogy egy általános benyomást szerezzünk a szakemberektől az ágazatban lévő jelenlegi trendekröl, és a trendek között kapcsolódásokat ismerjünk fel. További célunk, hogy teszteljük a mintavételezési - és kiértékelési módszerünket. Ezek miatt felmérésünkben a kvalitatív kutatás [3] mélyebb, az árnyaltabb véleményeket tükröző előnyeit ötvöztük a kvantitatív kérdőívek [9] nagyobb elemszámával.

A tanulmány az alábbi fejezetekböl áll: A 2. fejezetben a mintavételezés folyamatát mutatjuk be és kategorizáljuk a kapott eredményeket. A 3. fejezetben a válaszok közötti összefüggéseket tárjuk fel. Végezetül a Szerzők összegzi a tanulmány eredményeit és megfogalmazza a jövőbeni kutatási célkitüzéseiket.

\section{A felmérés folyamata}

Mikro-kísérletünk során a kérdőív kitöltői listájának összeállítása nem volt teljesen egyértelmü, mivel nem létezik egy egységes, megbízható adatbázis a magyarországi járműipari szereplőkröl. A lista elkészítéséhez először is vettük a különböző autóipari klaszterek tagjait, úgymint az ÉszakMagyarországi Autóipari Klaszter [4], az Alföldi Regionális Iparfejlesztési Klaszter [1], a Hírős Beszállítói Klaszter [5] és a Magyar Jármüfejlesztési Klaszter [8] elemeit. Ezen kívül felhasználtuk az Autopro [2] online elérhető cégadatbázisát, amivel összeállt a potenciális kitöltők köre.

A kiküldött 134 darab kérdőívre 18 választ kaptunk. A felmérésünk reprezentativitása elvileg megkérdőjelezhető. De - véleményünk szerint - a válaszadók egyértelműen reprezentálják kérdéskörrel kapcsolatban elkötelezett szakemberek véleményét.

\subsection{A kérdöív tartalma}

Mind a három kérdést szabad kifejtős formában határoztuk meg, hogy az összes rejtett vélemény felszínre kerüljön. Illetve mint a három válasznál három szempontot kértünk, amivel a válaszok közötti kapcsolódásokat tudjuk növelni.

A szakemberek modern gyárakról és fejlett karbantartásról szóló véleményének megismeréséhez a kérdőívben az alábbi három kérdést fogalmaztuk meg:

1. Ön milyen tulajdonságok alapján jellemezné egy gyár általános fejlettségi szintjét? Kérem, adjon meg három szempontot!

2. Ön milyen tulajdonságok alapján jellemezné egy karbantartási folyamat fejlettségét? Kérem, adjon meg három szempontot!

3. Ön hogyan jellemezne egy okos gyárat? Kérem, adjon meg három szempontot!

\subsection{Az eredmények rendszerezése}

A kérdőívet összesen 18 válaszadó töltötte ki, és a feldolgozásuk után mindegyik választ felhasználhatónak ítéltünk meg. Így az első körös kitöltéssel kapcsolatban már elegendő adattal rendelkeztünk arról, hogy a szakemberek véleményéröl egy következtetések levonására alkalmas képet kapjunk, és vizsgálni tudjuk a különbözö trendek közötti összefüggéseket.

A válaszokat ugyan szöveges formátumban kaptuk meg, azonban minden válasz tartalmazott jellemző témákat. Például, az első kérdésre adott egy konkrét válasz:

$$
\text { „géppark; tőke; vezetőség”. }
$$

Mivel mind a három kifejtős kérdésnél három válaszrészt kértünk, mindenhol három különböző 
szempontot is kaptunk. Ezeket a szempontokat külön válaszként kezeltük. A megfelelö összehasonlítás érdekében a szempontokat csoportosítottuk, vagyis témájukat tekintve bizonyos jellemző halmazba soroltuk, majd a csoportokat elneveztük jellemzőjük alapján. A fenti példában a "géppark” válaszrészt a Technológia és innováció csoportba, a „tőke” válaszrészt a Piac és financiális folyamat csoportba, a „vezetőség” választ pedig a Humán csoportba soroltuk.

$$
\begin{array}{ccc}
\text { "géppark" } & \text {,tőke” } & \text { "vezetőség" } \\
\{13\} & \{12\} & \{16\}
\end{array}
$$

Így létrejöttek a különböző csoportok. Például az első kérdés \{14\} Digitalizálás és nyomon követés csoportjába az alábbi témájú válaszok kerültek:

- Ipar 4.0 fejlettség;

- digitalizáltság;

- Ipar 4.0 bevezetése;

- valós idejü termeléskövetés;

- digitalizáltság;

- digitális fejlettség;

- digitalizáltság;

- nyomon követhetöség.

A csoportosítást elvégeztük mind a három kérdés összes válaszánál, így kaptunk egy jól öszszehasonlítható információ tömböt. A csoportok összeszámolása után kérdésenként egy-egy táblázatot kaptuk (lásd 1.-3. Táblázat). Ezekben a táblázatokban az egyes csoportokat növekvő sorrendbe soroltuk, és egyedileg azonosítottuk (például, az 1. kérdésnél $\{1 X\}$ a száma).

1. Táblázat. Egy gyár általános fejlettségi szintjének jellemzői

\begin{tabular}{|c|l|r|}
\hline$N r$. & \multicolumn{1}{|c|}{ Megnevezés } & $d b$ \\
\hline$\{11\}$ & $\begin{array}{l}\text { Hatékonyság, minőség és szállítási } \\
\text { megbízhatóság }\end{array}$ & 10 \\
\hline$\{12\}$ & Piac és financiális folyamat & 9 \\
\hline$\{13\}$ & Technológia és innováció & 8 \\
\hline$\{14\}$ & Digitalizálás és nyomon követés & 8 \\
\hline$\{15\}$ & Automatizálás & 7 \\
\hline$\{16$. & Humán & 5 \\
\hline$\{17\}$ & Egyéb & 4 \\
\hline$\{18\}$ & Folyamatszemlélet & 3 \\
\hline
\end{tabular}

2. Táblázat. Egy karbantartási folyamat fejlettségének jellemzői

\begin{tabular}{|c|l|r|}
\hline Nr. & \multicolumn{1}{|c|}{ Megnevezés } & $d b$ \\
\hline$\{21\}$ & Követhetőség, mérhetőség & 11 \\
\hline$\{22\}$ & Tervezhetőség & 9 \\
\hline$\{23\}$ & Szakszerüség & 7 \\
\hline$\{24\}$ & $\begin{array}{l}\text { Megelőző jellegü, preventív-predik- } \\
\text { tív arány }\end{array}$ & 6 \\
\hline$\{25\}$ & Gyorsaság & 5 \\
\hline$\{26\}$ & Géppark és felszerelések & 4 \\
\hline$\{27\}$ & Rendszeresség & 4 \\
\hline$\{28\}$ & Költség hatékonyság & 4 \\
\hline
\end{tabular}




\section{Táblázat. Egy okos gyár jellemzői}

\begin{tabular}{|c|l|r|}
\hline Nr. & \multicolumn{1}{|c|}{ Megnevezés } & $d b$ \\
\hline$\{31\}$ & Digitalizálás & 14 \\
\hline$\{32\}$ & Gyorsaság, hatékonyság & 10 \\
\hline$\{33\}$ & Automatizálás & 9 \\
\hline$\{34\}$ & Folyamatközpontúság & 5 \\
\hline$\{35\}$ & Tervezhetőség & 4 \\
\hline$\{36\}$ & Kommunikáció & 4 \\
\hline$\{37\}$ & Környezetvédelem & 2 \\
\hline$\{38\}$ & Egyéb & 1 \\
\hline
\end{tabular}

\subsection{A vélemények kapcsolódásai}

Ahhoz, hogy a karbantartási folyamatok fejlettsége és a modern gyárak közötti összefüggést feltárjuk, megvizsgáltuk az egyes válaszok közötti kapcsolatokat. Feljegyeztük azt, hogy ha egy válaszadó az egyik kérdésre adott válasza után a következő kérdésre milyen választ adott. Ez alapján kaptunk három kapcsolódási mátrixot (1. kérdés - 2. kérdés, 2. kérdés - 3. kérdés és 1 . kérdés -3. kérdés). Ezt a három mátrixot egyesítettük egy közös hálózatban, amit az 1. ábra szemléltet.
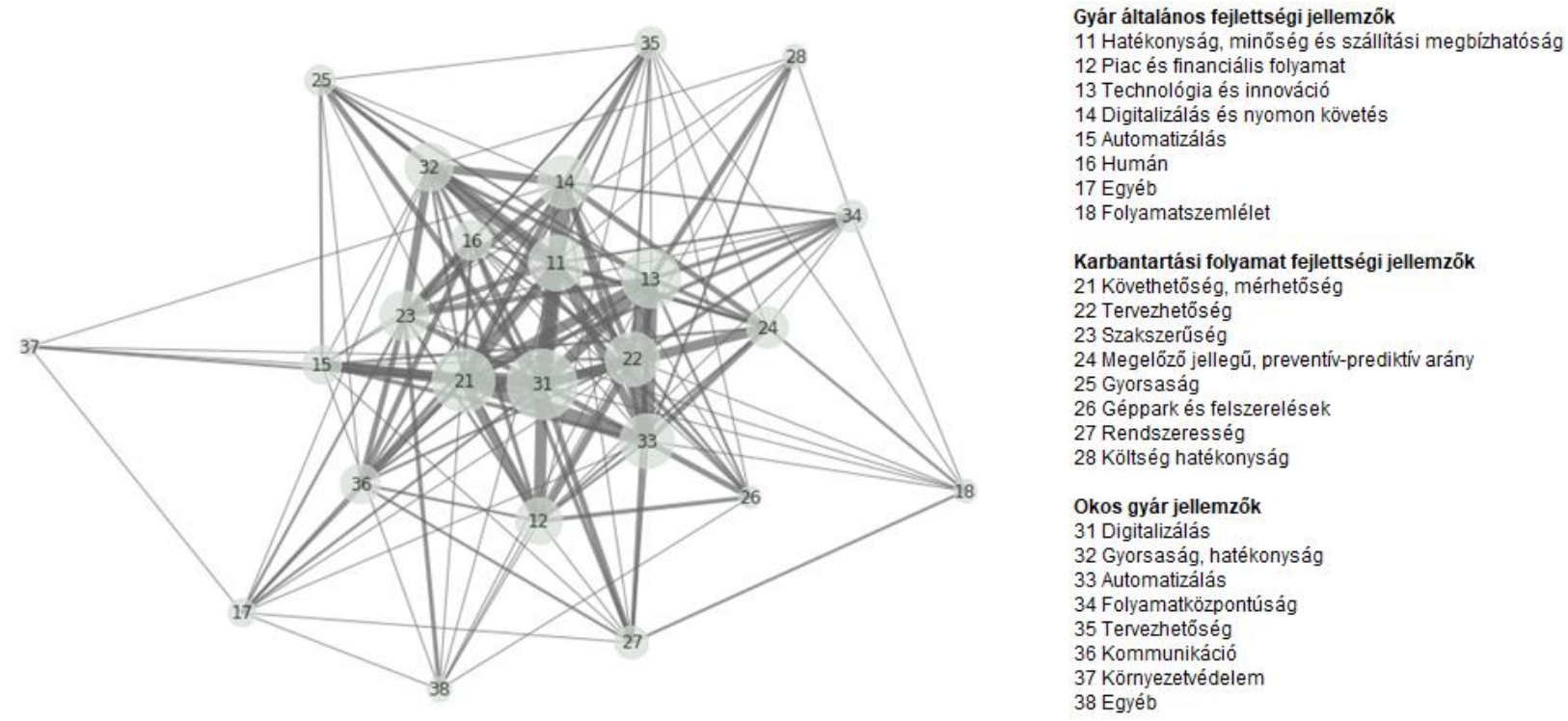

1. ábra Az összes válasz közötti kapcsolati gráf

Egy csomópont másik csomóponthoz lévő kapcsolódását mutatja az egymáshoz képesti távolságuk és a közöttük lévő vonal vastagsága. A csomópontok méretét pedig az összes kapcsolatuk száma határozza meg.

Azt tekintjük releváns kapcsolódásnak, ahol a csomópontok között minimum hatos kapcsolódás állapítható meg, mivel ez pontosan a válaszadók egyharmadára jellemző. Az elemzésben nem csak egyirányú függést elemeztük két kérdés között, hanem a három kérdés együttes függését vizsgáltuk olyan szempontból, hogy a három kérdés mely válaszoknál alkot releváns kapcsolódási háromszöget. Ezek alapján ugyanúgy kaptunk három kapcsolódási mátrixot egyesítettünk és azt a 2. ábrán szemléltetünk. 


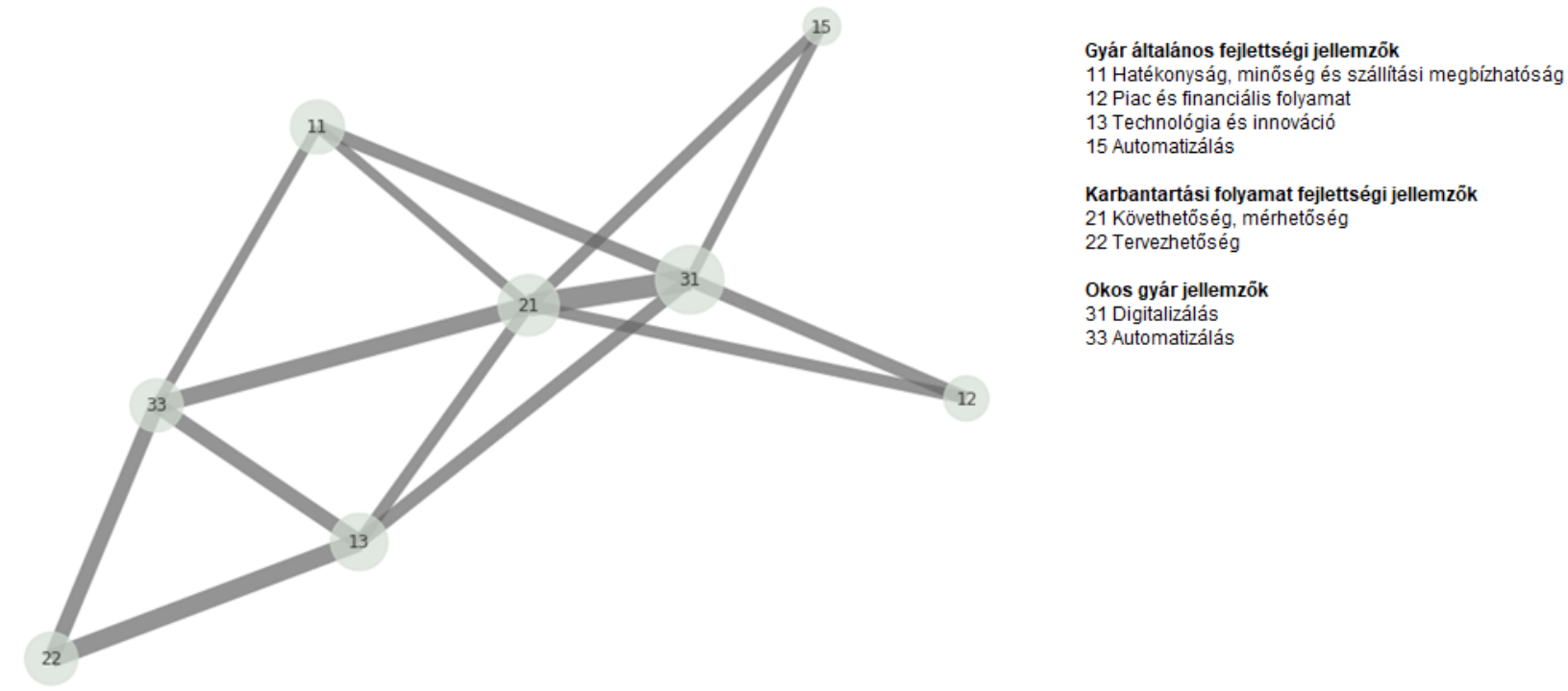

2. ábra A kiemelt kapcsolódást mutató válaszok közötti kapcsolati gráf

\section{Következtetések} össze:

A kapott válaszok kiértékelése alapján levonható következtetések az alábbiakban foglaljuk

- A legerősebb kapcsolat a karbantartásra vonatkozó \{21\} Követhetőség, mérhetőség és az okos gyárakra vonatkozó \{31\} Digitalizálás között található, ami a saját válaszcsoportjukban is az első helyen szerepelnek.

- Ehhez a fő kapcsolathoz hozzávetölegesen egyenlö arányban kapcsolódik a gyárak fejlettségére vonatkozó \{11\} Hatékonyság, minőség és szállitás, a \{12\} Piac és financiális folyamat, a \{13\} Technológia és innováció és a \{15\} Automatizálás.

- A „\{11\} Hatékonyság, minőség és szállitás - \{21\} Követhetőség, mérhetőség - $\{31\}$ Digitalizálás" háromszög egyértelműen a korszerü minőségkultúra jelenlétét mutatja a válaszadó, a fejlődés iránt elkötelezett karbantartó szakemberek körében. A minőségbiztositás egyik kulcskérdése a nyomon-követhetőség, melyet - az Ipar 4.0 térnyerésével - digitális formát vehet fel.

- Hasonló következtetés vonható le a „\{12\} Piac és financiális folyamat - \{21\} Követhetőség, mérhetőség - \{31\} Digitalizálás” háromszög is. Ne feledjük, a minőséget, mint vevői elégedettséget is megfogalmazzák a szakértők.

- Viszonylag erősebb hármas összefüggés fedezhető fel a fejlett gyárak \{13\} Technológia és innováció, a modern karbantartás \{22\} Tervezhetőség és az okos gyárak \{33\} Automatizálásával.

- A fejlett gyár \{14\} Digitalizálása és az okos gyárak \{31\} Digitalizálása között nem fedezhető fel számottevő kapcsolat. A szakemberek eszerint az okos gyárak elérését a digitalizálásban látják első sorban, viszont egy általános fejlett gyárat pedig főleg nem ezzel jellemeznek, hanem például a \{11\} Hatékonyság, minőség és szállítási megbízhatósággal.

\section{4. Összefoglalás}

Tanulmányunkban egy mikro-kísérletet és annak elsődleges eredményeit mutattuk be. A felméréssel a célunk nem csak az volt, hogy rávilágítsunk a hazai járműipar aktuális állapotára, hanem az, hogy elsődleges benyomásokat szerezzünk a kérdéskör iránt fogékony szakemberektől az ágazatban lévő jelenlegi trendekről, és a trendek között kapcsolódásokat ismerjünk fel. További célunk volt a mintavételezési - és kiértékelési módszerünk tesztelése. A tanulmány elkészítése során szerzett tapasztalataink alapján egy szélesebb körü és mélyebb felmérés kidolgozását és lebonyolítását tervezzük a közeljövőben. 


\section{Köszönetnyilvánítás}

A cikk az Innovációs és Technológiai Minisztérium és a Nemzeti Kutatási, Fejlesztési és Innovációs Alap Új Nemzeti Kiválóság 2020 Programjának támogatásával készült.
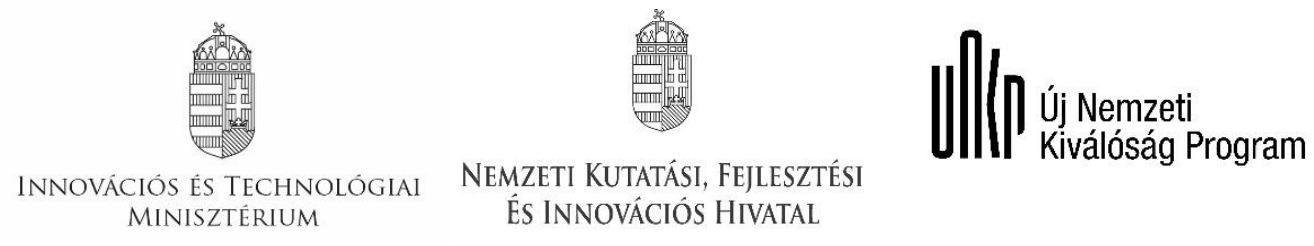

\section{Irodalomjegyzék}

[1] Alföldi Regionális Iparfejlesztési Klaszter tagjai http://www.aipa.hu/partnerek (utolsó letöltés: 2020.11.23.)

[2] Autopro online beszállítói adatbázis https://autopro.hu/katalogus/ (utolsó letöltés: 2020.11.23.)

[3] Babble E.: A társadalomtudományi kutatás gyakorlata, Balassi Kiadó, Budapest, 2003., p. 704., ISBN: 9789634560005

[4] Észak-Magyarországi Autóipari Klaszter http://nohac.hu/index.php/hu/tagjaink (utolsó letöltés: 2020.11.23.)

[5] Hírős Beszállítói Klaszter tagjai http://www.hirosklaszter.hu/hu/klasztertagok utolsó letöltés: 2020.11.23.)

[6] Juhász L, Pokorádi L.: A Dolgok Internete és a karbantartás közötti kapcsolat napjainkban, GRADUS 51 pp. 99 106., http://gradus.kefo.hu/archive/2018-1/2018 1 ENG 001 Juhasz.pdf

[7] Juhász L., Pokorádi L.: Kiterjesztett valóság a modern karbantartásban, Repüléstudományi Közlemények XXX: 2 pp. 37-46., 10 p., http://www.repulestudomany.hu/folyoirat/2018 2/2018-2-03-0449 Juhasz LaszloPokoradi Laszlo.pdf

[8] Magyar Jármüfejlesztési Klaszter tagjai http://www.autoipari-klaszter.hu (utolsó letöltés: 2020.11.23.)

[9] Martin, W., Bridgmon, K.: Quantitative and statistical research methods: from hypothesis to results. New Jersey, USA: Jossey-Bass 2012., ISBN: 978-0-470-63182-9.

[10] Morauszki K.: Autóipari beszállítói értékelési és kiválasztási kritériumrendszer vizsgálata és elemzése minőségügyi aspektusból, Szent István Egyetem, Gazdálkodás és Szervezéstudományok Doktori Iskola, 2019., https://archive2020.szie.hu/sites/default/files/morauszki kinga ertekezes.pdf 